\title{
Environmental Consequences of the Demise in Swidden Cultivation in Southeast Asia: Carbon Storage and Soil Quality
}

\author{
Thilde Bech Bruun • Andreas de Neergaard • \\ Deborah Lawrence • Alan D. Ziegler
}

Published online: 16 June 2009

(C) Springer Science + Business Media, LLC 2009

\begin{abstract}
The effects of swidden cultivation on carbon storage and soil quality are outlined and compared to the effects of the intensified production systems that swidden systems of Southeast Asia transform into. Time-averaged aboveground carbon stocks decline by about $90 \%$ if the long fallow periods of traditional swidden cultivation are reduced to 4 years and by about $60 \%$ if swidden cultivation is converted to oil palm plantations. Stocks of soil organic carbon (SOC) in tree plantations are $0-40 \%$ lower than stocks in swidden cultivation, with the largest losses found in mechanically established oil palm plantations. Impacts of tree plantations on soil quality are to a large extent determined by management. Conversion of swiddening to continuous annual cropping systems brings about substantial losses of time-averaged aboveground carbon stocks, reductions of SOC stocks and generally leads to declining soil quality. Knowledge of carbon storage in belowground
\end{abstract}

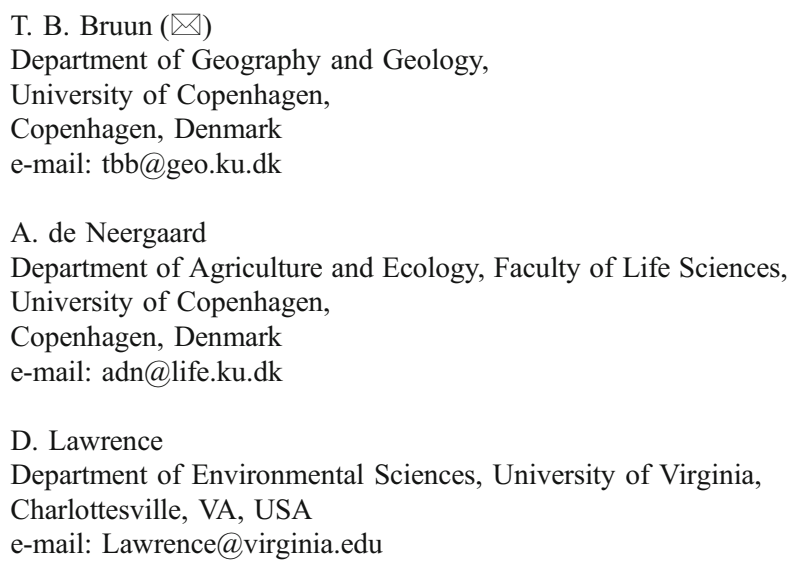

biomass of tree based systems of the tropics is sparse but failure to include this pool in carbon inventories may significantly underestimate the total biomass of the systems. Moreover, studies that consider the ecological reasons behind farmers' land use decisions as well as spatial variability in biogeophysical and edaphological parameters are needed to evaluate the effects of the ongoing land use transitions in Southeast Asia.

Keywords Swidden cultivation - Land use transformation · Soil quality · Soil organic carbon .

Time-averaged aboveground carbon stocks

\section{Introduction}

The last few decades have seen a rapid transformation of swidden cultivation throughout Southeast Asia (Padoch et al. 2007). The scale and nature of these changes are still not well understood, but a recent review of 151 studies of swidden cultivation across Southeast Asia suggests that the system is mainly being replaced by continuous annual cropping or by perennial crops such as rubber, fruit trees, oil palm or timber (Schmidt-Vogt et al. 2009). Evidence of persisting swidden systems was, however, found in half of the reviewed papers although it is noted that the majority of the persisting systems are in transformation as fallow periods are reported to be decreasing (Schmidt-Vogt et al. 2009).

Swidden cultivation is a natural resource management strategy that involves rotation of fields rather than crops and relies on the use of fallow to sustain the production of food crops. The fallows are cleared by means of slashing and burning, the land is cropped for a short period of time and then left untended while the natural vegetation 
regenerates. Swidden cultivation is the traditional land use system in the sloping uplands of Southeast Asia and although the sloping uplands is the most extensive landscape in Southeast Asia (Garrity 1993), knowledge of the land use types and soil properties of the area is limited compared to the much more investigated lowlands of the region (Aumtong et al. 2009; Roder et al. 1997). Regardless of a lack of substantiating data, the swidden systems in the upland areas have frequently been deemed environmentally destructive causing deforestation, soil degradation in terms of erosion and negative nutrient balances and contributing to $\mathrm{CO}_{2}$ emissions (Brady 1996; Devendra and Thomas 2002; Harwood 1996). This perception is, however, increasingly challenged as numerous studies have shown that swidden cultivation in many situations can be a rational economic and environmental choice for resource poor farmers and that swidden cultivation besides being a production system provides a range of ecosystem services in terms of hydrology, biodiversity and carbon storage in soil and vegetation (Fox 2000; Kleinman et al. 1995, 1996; Nielsen et al. 2006; Rerkasem et al. 2009; Ziegler et al. 2009).

The transformations of swidden cultivation have a wide range of environmental consequences at the local and at the global level. The Intergovernmental Panel on Climate Change (IPCC) currently estimates that land use change accounts for $20 \%$ of global anthropogenic carbon emissions (IPCC 2007). Estimates of the yearly contribution of $\mathrm{CO}_{2}$ from land use and land cover changes taking place in Southeast Asia during the 1990's range from 0.3 to $0.5 \mathrm{Gt}$ $\mathrm{C}$ year ${ }^{-1}$ (Achard et al. 2002). These $\mathrm{CO}_{2}$ emissions arise from changes in the pool of organic carbon in the aboveground biomass and in the pool of soil organic carbon (SOC) following land use transitions. The focus of this paper is on the effects of swidden transformations on the global carbon budget in terms of carbon storage in soil and vegetation and on the effects at plot level in terms of the effects on soil quality.

\section{Aboveground Carbon}

The global pool of carbon in the aboveground biomass contains about $610 \mathrm{Pg}$ of carbon (Grace 2004). Compared to natural forests all other land uses will lead to a reduction of the carbon stock in the aboveground biomass. Tropical lowland rain forests have the highest aboveground carbon stocks of any vegetation type in the world and estimates of the stocks in the primary forests of Southeast Asia range from 254 to as much as $647 \mathrm{Mg} \mathrm{C} \mathrm{ha}^{-1}$ (Foody et al. 2001; Murdiyarso et al. 2002).

The aboveground carbon storage potential of a land use system is not determined by the carbon stocks at any point in time, but by the average amount of carbon stored in the system during its' rotation time. This quantity is referred to as the time-averaged aboveground carbon stock and depends on the carbon accumulation rates and the maximum and minimum amounts of carbon stored in the system during a full rotation. Time-averaged carbon stock is calculated by summing up the carbon stock of the standing crop for every year in the rotation and dividing by the length of the rotation (Palm et al. 2005). Thus the use of time-averaged aboveground carbon stock allows for comparisons of systems with different rotation times.

\section{Soil Quality}

Soil quality is here defined as the capacity of the soil to support plant growth without causing degradation of the soil or the environment (Carter et al. 1997; Doran and Parkin 1994). According to this definition the term encompasses chemical, physical and biological parameters such as contents of nutrients and soil organic matter as well as $\mathrm{pH}$ level, $\mathrm{pH}$ buffering capacity, soil structure and microbial activity. Soil quality is closely linked to soil resilience which refers to the ability of the soil to restore soil functions following disturbance-resilient soils have a high soil quality and vice versa (Lal 1997; Lal and Bruce 1999). Consequently, the impact of land use on soil quality can be used as a proxy for the possibilities of reversal after land use change.

\section{Soil Organic Carbon}

Soil organic matter is the organic fraction of the soil and consists of a large fraction of highly decomposed humic substances, fresh and partly decomposed plant residues and a small fraction of living soil microbial biomass. Soil organic matter contains approximately 58\% $\mathrm{C}$ and in this paper carbon associated with soil organic matter is termed soil organic carbon (SOC). SOC is of environmental importance both at the global and at the local scale.

At the global scale, the pool of SOC is of environmental importance as it is one of the major components of the global carbon cycle and may act both as a source and as a sink of $\mathrm{CO}_{2}$. The top meter of the world's soils contains an estimated 1,550 Pg SOC (Batjes 1996) in active exchange with the atmosphere. By comparison, the atmosphere contains half of this amount. The global emission of $\mathrm{CO}_{2}$ from the SOC pool is recognized as one of the largest fluxes in the global carbon cycle equalling the total photosynthetic uptake (Schlesinger and Andrews 2000).

At the local scale, the maintenance of the pool of SOC is closely linked to soil quality; it is essential to sustaining the long term productivity of agricultural soils-especially when nutrient poor soils are managed with limited use of external inputs as is often the case within small scale 
tropical agriculture. Under these conditions SOC acts as an important pool of nutrients, a significant source of cation exchange capacity and as a buffer against acidity and aluminium toxicity (Sanchez 1976; Szott et al. 1999). SOC is also a key determinant of soil structure, improving soil aggregation and enhancing water infiltration, thereby reducing erosion risk and improving water use efficiency (Young 1997).

The pool of SOC represents a dynamic equilibrium of gains and losses. Under natural vegetation organic carbon enters the soil through litterfall, root turnover and root exudates. Some of the added organic carbon is lost from the soil through respiration during decomposition and a fraction of the decomposing organic carbon is stabilized in humus. Under steady state conditions the carbon gain is matched by equivalent carbon losses from the soil through decomposition of litter and of soil organic matter (Murty et al. 2002).

Conversion of natural forest to cultivated land generally leads to a reduction of the SOC stock (Davidson and Ackerman 1993; Detwiler 1986; Murty et al. 2002; Nye and Greenland 1964). This reduction is mainly due to (1) reduced litter inputs (2) higher top soil temperatures that lead to higher decomposition rates and (3) soil disturbance that increases decomposition due to increased aeration and destruction of physiochemical protection mechanisms (Schlesinger and Andrews 2000; Tinker et al. 1996; van Noordwijk et al. 1997). The magnitude of changes in the SOC stock depends on the specific land use for which a forest is cleared and on a variety of other factors including climate, soil type and management practices.

Evaluation of the Environmental Consequences of Swidden Transformations

The environmental aspects of swidden cultivation have frequently been evaluated against the environmental characteristics of primary forests. This comparison is in several ways problematic, most fundamentally because a primary forest is not a production system, thus for the farmers forests do not represent an alternative to swidden cultivation.

In the following sections the major effects of swiddening on soil quality and carbon storage in soil and vegetation are outlined. These effects are then compared to the productionbased land use types that swidden transforms into, namely intensified short rotation swidden systems, continuous annual cropping systems and perennial plantations.

Due to the paucity of studies on the ecological aspects of land use in the areas used for swidden cultivation in Southeast Asia, the review also encompasses studies from other parts of the humid tropics. These studies all focus on land use systems that in an ecological sense are managed in ways that can be compared to the management of swidden systems in Southeast Asia.

\section{Swidden Cultivation}

The essential ecological principles of swidden cultivation are that during the fallow phase nutrients are taken up by the recolonizing natural vegetation and returned to the soil surface as litter. The nutrients accumulated in the aboveground biomass are made available to the subsequent crop when the fallow is cut down and burned. No tillage takes place and the input of inorganic fertilizers is generally very limited.

The continued productivity of swidden systems relies on two factors - the comparably low productivity per area unit over a timescale, hence a low net export of nutrients, and the conversion of the soil pool of chemically largely unavailable nutrients to a bioavailable form during the fallow and subsequent burning. Even highly weathered infertile soils contain considerable total amounts of plant nutrients; however the release to bioavailable forms is too slow to allow high crop production.

Dynamics of the Aboveground Biomass during the Fallow Phase

Under the same climate conditions, fallow growth can vary as a result of interactions among vegetation, soil type, land use history and management. The number of cultivation cycles, prolonged cropping periods or large size of cropped fields can reduce the quantity of seeds and sprouts available for fallow recolonization leading to reduced rates of biomass and nutrient accumulation (Ewel et al. 1981; Jordan 1989; Lawrence et al. 2005; Szott et al. 1999; Uhl 1987).

Biomass accumulation by natural secondary vegetation in the tropics is essentially linear during the first 10 years of growth and the accumulation rates are more related to rainfall and climate zone than to soil fertility (Szott et al. 1999). In the humid tropics rates of biomass accumulation during the first 10 years of fallow range from 4-20 Mg ha ${ }^{-1}$ year $^{-1}$ (Halenda 1989; Hashimotio et al. 2000; Hughes et al. 2000; Jepsen 2006; Lawrence et al. 2005; Uhl 1987).

Pioneer species typically produce a large volume of low density wood and are characterized by being lightdemanding and well adapted to survive in nutrient poor environments. These species generally allocate a lot of energy to the production of root biomass thus have a high root:shoot ratio thus allocate a relatively large amount of carbon to the deeper soil layers. They also often host mycorrhizal fungi that enhance nutrient uptake, especially with respect to phosphorus. Therefore, the pioneer species occurring in fallows are able to take up nutrients even when soil solution concentrations are very low and the species are considered important for a closed recycling of nutrients (Andriesse 1989; Uhl 1987). 
The initial phase of rapid regrowth is followed by a period of slower growth. Data on the amount of biomass stored in the fallow during this period varies from 24$160 \mathrm{Mg} \mathrm{ha}^{-1}$ (Halenda 1989; Hashimotio et al. 2000; Jepsen 2006; Szott et al. 1999).

After several decades (50-100 years), very little net accumulation of biomass may occur while long-lived pioneer species and early successional species are gradually being replaced by the slow growing primary forest species (Jepsen 2006; Johnson et al. 2001; Uhl 1987). Biomass stocks in this phase are on the order of $15-45 \%$ of the amount stored in the primary forest and how fast the regrowth will reach biomass amounts similar to non-logged forests remains uncertain (Jepsen 2006; Szott et al. 1999).

The time-averaged aboveground carbon stock of swidden systems with long fallow periods ( $>20$ years) has been reported to be about $80 \mathrm{MgC} \mathrm{ha}^{-1}$ (Palm et al. 2005).

Dynamics of SOC and Nutrients during Fallowing

The content of SOC may decrease during the early establishment of the fallow vegetation, but this initial decrease is followed by a progressive build up of SOC during the fallow period. Increases in the active fraction of SOC as well as in the size and diversity of the microbial biomass during the fallow period are important factors contributing to the recovery of soil fertility during the fallowing (Sarmiento and Bottner 2002). The SOC dynamics during fallowing partly determine the dynamics of $\mathrm{N}, \mathrm{S}$ and $\mathrm{P}$ as most of these nutrients are located in the organic fraction of the soil and because $\mathrm{N}$ and $\mathrm{P}$ to some extent are lost during burning. Thus the supply of these nutrients depends on microbial activity and physical and geochemical characteristics of the soil (Roder et al. 1997) whereas a large proportion of the basic cations and micronutrients is stored in the biomass of the fallow vegetation (Andriesse and Schelhaas 1987a; Hughes et al. 2000; Jordan 1985).

The effects of swidden systems on the stock of nutrients and SOC depend on the balance between the accumulation of SOC and nutrients during the fallow period and the dynamics during clearing, burning and cultivation. Whereas several studies have investigated the dynamics of SOC and nutrients in swidden systems based on measurement taken at one point in time, studies that quantify the dynamics during an entire cropping and fallow period are sparse (Roder et al. 1997) and those that quantify these dynamics over multiple crop-fallow cycles are even more so (Lawrence et al. 2007).

\section{Nutrient Dynamics during Burning and Cropping}

The burning of the fallow vegetation transforms the nutrient stock of the aboveground biomass into plant available forms, kills a part of the weed seed bank and clears the land for cropping. The burning leads to increased nutrient availability in the soil due to additions of nutrient rich ash and due to the effects of burning per se. Amounts of mineral nutrients found in the ash are primarily dependent on total nutrient content in the biomass, the temperature thresholds of the respective nutrient elements, and the intensity of burning.

Depending on the intensity of burning and degree of combustion, a part of the $\mathrm{N}$ and $\mathrm{S}$ in the biomass will be volatilized and lost to the atmosphere (Giardina et al. 2000; Hölscher et al. 1997; Romanyá et al. 2001). Although erosive and convective P losses have also been documented (Ewel et al. 1981; Giardina et al. 2000; Kauffman et al. 1993), volatilization losses of $P$ are generally low and significant amounts of $\mathrm{P}$ in the ash immediately after fires have been reported (DeBano et al. 1998; Romanyá et al. 2001). The transfer of basic cations from the aboveground vegetation to the ash is typically also high and ash deposits are considered the most important input of basic cations in swidden systems (Juo and Manu 1996; Kennard and Gholz 2001).

Several studies have documented increased soil $\mathrm{pH}$ levels following burning. These increases are mainly a result of the acid neutralizing capacity of the ash (Giardina et al. 2000). In acid soils with variable charge minerals the increase in soil $\mathrm{pH}$ will increase the cation exchange capacity (CEC) in surface soils, reduce the level of soluble and exchangeable $\mathrm{Al}$ leading to reduced risk of $\mathrm{Al}$ toxicity. The geochemical transformations will increase the availability of $\mathrm{P}$ as will pyromineralization of organically bound $\mathrm{P}$ already in the soil (Andriesse and Schelhaas 1987b; Lawrence and Schlesinger 2001; Nye and Greenland 1964; Saa et al. 1993; Sanchez 1976).

Burning can cause high rates of microbial mortality, but this will be followed by a rapid recovery to above pre-burn levels as microbial activity is stimulated by increased temperatures, enhanced nutrient availability, inputs of labile $\mathrm{C}$ and under some circumstances by increased soil moisture following burning (Andriesse and Koopmans 1984; Giardina et al. 2000). Consequently, increased rates of mineralization following burning have often been observed (Arunachalam 2002; Nye and Greenland 1964; Palm et al. 1996, 2005). The increased rates of mineralization result in increased amounts of plant available $\mathrm{N}$ and $\mathrm{P}$ in the beginning of the cropping period.

As most nutrients - excluding nitrogen and partially sulphur-are only deposited from the atmosphere in negligible amounts, the nutrient balance of low or noninput swidden cultivation systems is invariably negative. The deposition of nitrogen and sulphur will predominantly depend on proximity to industrial and urban centres with fossil fuel emissions, or intensified agricultural production 
sites with ammonia emissions. As swidden systems are typically practiced in remote rural areas, these inputs will most often also be limited. Biological fixation may hence be the only significant external source of plant nutrients.

\section{SOC Dynamics during Burning and Cropping}

Reviewing SOC dynamics following land use changes in the humid tropics, Detwiler (1986) found that soils used for swiddening loses about $18-27 \%$ SOC during the first 2 years of cropping. This estimate may serve as a guideline, but it could be argued that the effects of swiddening on SOC stocks should be evaluated over the entire croppingfallow cycle and not at the end of the cropping period. Moreover, the SOC dynamics of swidden cultivation are extremely variable. Accordingly, studies of soil carbon dynamics in swidden cultivation systems are far from unambiguous and gains, losses as well as absence of changes of carbon levels in soils used for swiddening have been reported.

Heat development during the burning of the fallow vegetation can cause thermally induced losses of SOC but these are typically small (Arunachalam 2002; Giardina et al. 2000). On the contrary, contents of SOC in the topsoil are often reported to increase by 10-30\% following burning (Andriesse and Schelhaas 1987a; Lal and Cummings 1979; Nye and Greenland 1964). The increase is mainly ascribed to the entry of uncombusted particulates and to carbonized litter.

SOC losses in swidden systems can mainly be ascribed to the increased mineralization during the cropping period. The input of organic matter from litter may also decrease during the cultivation and regrowth stages. Finally, topsoil erosion may cause an apparent decrease in soil carbon as the subsoil layers usually contain less organic matter. Based on observed respiration rates, Funakawa et al. (1997) estimated that nearly $10 \%$ of the SOC found in the upper $50 \mathrm{~cm}$ of the soil profile would decompose during the first year of cropping in a swidden system in an upland area of Northern Thailand. It is, however, difficult to separate $\mathrm{CO}_{2}$ derived from decomposing SOC from $\mathrm{CO}_{2}$ derived from decomposing dead roots of the slashed vegetation.

Several studies looking at the whole fallow-cropping cycle of swidden systems in Borneo have found SOC contents to be unaffected by swiddening (Bruun et al. 2006; Kleinman et al. 1996; Mertz et al. 2008). In another study from Borneo, de Neergaard et al. (2008) found that neither SOC concentration (\%) nor total content was affected by swiddening in soil layers down to $90 \mathrm{~cm}$ depth. Similar findings are reported by Sommer et al. (2000), who examined the upper $6 \mathrm{~m}$ of an Ultisol in Brazil.

SOC content increased significantly with the number of prior cultivation cycles at a site in Kalimantan (Lawrence et al. 2005). Contents of SOC were not related to inherent soil properties but may have been linked to the decomposition of roots from the slashed and burned forest following the conversion to agriculture and subsequent fallows. A study from calcareous soils in Mexico reports the content of SOC to decline after the first cultivation cycle but SOC did not decline further with subsequent crop-fallow cycles (Eaton and Lawrence 2009).

\section{Reduced Fallow Periods}

When a swidden system is intensified by reducing the fallow periods there will be an increased tendency of net negative nutrient balance in the soil system as nutrients are lost through burning, crop harvest, and leaching. This tendency has formed the basis of the conventional understanding of swidden systems according to which the intensification of the systems by shortening the fallow periods will cause environmental degradation in terms of decreasing soil fertility, increased erosion and declining yields until the system finally collapses (Greenland 1975; Juo and Manu 1996; Ruthenberg 1980; Szott et al. 1999; Whitmore 1998). The supposed positive relationship between fallow periods and soil productivity may, however, not be as straightforward as usually presented in the literature. The empirical evidence to support this assumption has proved to be scarce and few studies have convincingly documented a causal relationship between fallow lengths, soil nutrient levels and yields (Mertz 2002).

Studies documenting effects of fallow length on soil nutrient levels include test site based surveys from India that found a positive relationship between fallow length and post burn contents of exchangeable bases (Ramakrishnan and Toky 1981; Swamy and Ramakrishnan 1988) and levels of plant available P (Ramakrishnan and Toky 1981). In a study from Sarawak, the length of the fallow was linked to post burn levels of plant available $\mathrm{N}$ as well as to the yield of upland rice, but no signs of long term degradation of the soil resource and no relation between fallow length and SOC were found (Bruun et al. 2006). Finally, a study from Laos found weak correlations between fallow length and contents of SOC and between yield levels and contents of SOC (Roder et al. 1995).

A study with more than 4,500 observations from Malaysia and Indonesia found fallow length to be a weak predictor of yields and emphasizes that other factors such as weed pressure, labour input, water related problems and pests are more important than the length of the fallow period (Mertz et al. 2008). Other factors that confound the theoretical relationship between fallow length, soil nutrient contents and yields in the real world, include spatial variation in terms of topography and inherent soil quality. 
The theoretical relationship between fallow length and soil fertility may also be confounded by farmers' land use decisions. Several studies have demonstrated that land use intensity is not independent of inherent soil quality as farmers adapt land use according to soil quality indicators and use shorter fallow periods on the more fertile land (Aumtong et al. 2009; Roder et al. 1995). The number of prior cultivation cycles is therefore also likely to be higher on the more fertile land so if the land use history of a given plot is not properly addressed, the effects of fallow length will be even more confounded.

The land use history and the inherent soil fertility parameters were controlled for in a study of a swidden system with reduced fallow periods in Laos. The study that was based on farmer managed test sites and measured the nutrient dynamics during an entire cropping-fallow cycle, documents a continuous downward trend of total $\mathrm{N}$ and SOC during the 2 year fallow period (Roder et al. 1997). The overall balance for $\mathrm{K}$ was also negative even when accounting for the amount of $\mathrm{K}$ stored in the vegetation. The amount of $\mathrm{C}, \mathrm{N}$ and $\mathrm{K}$ stored in the aboveground biomass represented respectively $20 \%, 5 \%$ and $20 \%$ of the amounts lost from the soil pool during the rotation.

Based on data reported by Jepsen (2006) and Hashimotio et al. (2000), time-averaged aboveground carbon stocks of swidden systems with fallow periods of 4 years found on low fertility soils in Borneo were calculated to be $8-$ $9 \mathrm{Mg} \mathrm{C} \mathrm{ha}{ }^{-1}$, assuming a cropping period of 2 years, a grain yield of 1-2 $\mathrm{Mg} \mathrm{ha}^{-1}$, a harvest index of $50 \%$ and $45 \% \mathrm{C}$ in the biomass.

\section{Continuous Annual Cropping Systems}

The replacement of swidden cultivation with continuous annual cropping systems means intensification in terms of cropping frequency. It will in most cases also imply increased inputs of inorganic fertilizers and pesticides and the introduction of tillage ( Lal 2000).

The aboveground carbon storage in continuous annual cropping systems is lower than in all other land use types; it is on the order of $1-4 \mathrm{Mg} \mathrm{C} \mathrm{ha}^{-1}$ (assuming a grain crop yield of $1-4 \mathrm{Mg} \mathrm{ha}^{-1}$, a harvest index of $50 \%$ and $45 \% \mathrm{C}$ in the biomass) corresponding to a reduction of $95-99 \%$ compared with the time-averaged aboveground $\mathrm{C}$ stock of traditional swidden cultivation.

Losses of SOC following conversion of forest to continuous agriculture in terms of annual cropping are generally reported to be on the order of 20-40\% (Davidson and Ackerman 1993). Many studies indicate that losses are largest during the first years after conversion and that the SOC stock eventually will approach a new equilibrium (Davidson and Ackerman 1993; Detwiler 1986; Sanchez et al. 1982). Detwiler (1986) predicts a SOC loss of $40 \%$ during the first 5 years of cultivation after which the SOC level stabilizes at $60 \%$ of the level found under forest. Houghton et al. (1991) assumed a SOC decline of $20 \%$ after the clearing of forest land followed by an additional $5 \%$ decline over the next 20 years.

SOC changes in continuous annual cropping systems do, nevertheless, vary a lot and are affected by soil type (Feller and Beare 1997), climate (Jobbaggy and Jackson 2000), initial carbon content (Davidson and Ackerman 1993) and farm management practices such as tillage, cropped species, cropping pattern, use of cover crops, harvest index, manuring and residue management (Bruce et al. 1999; Ingram and Fernandes 2001; Lal 2004a, b).

Some of the effects of tillage are to disrupt the soil pore system and to break down the stable aggregates so previously encapsulated organic materials are exposed to soil microbes and mineralization rates are increased. The disruption of the soil structure will also favour SOC losses through erosion. Soil erosion may be the major factor contributing to SOC losses on sloping land whereas mineralization will usually predominate over erosion on relatively flat land (Lal 2004b). On site depletion of SOC from erosion does not necessarily lead to increased $\mathrm{CO}_{2}$ emissions as this will depend on the fate of the allocated carbon. The allocated SOC can be deposited, mineralized and released as $\mathrm{CO}_{2}$ or it can be buried and effectively removed from the carbon cycle. Erosion will, however, always result in a degradation of the on site soil quality as the selective removal of the top soil causes depletion of SOC and nutrients and exposes the poorly structured subsoil layers. This would then impact aboveground carbon storage through effects on the productivity of vegetation.

Elevated $\mathrm{CO}_{2}$ emissions from soils used for high input annual cropping systems have been documented in a study from the Peruvian Amazon (Mutuo et al. 2005). Measurements of soil respiration rates revealed that $\mathrm{CO}_{2}$ emissions from continuous annual cropping systems were $25 \%$ higher than from swidden systems. The higher emissions from the high-input system were attributed to the combined effects of numerous tillage operations and to elevated decomposition rates following $\mathrm{N}$ and $\mathrm{P}$ fertilization. Amounts of $\mathrm{CO}_{2}$ emitted from soils under high input annual cropping systems are, however, likely to be insignificant compared to emissions associated with transport and production in these systems.

Numerous studies of tropical lowland soils have documented that intensive tillage results in large SOC losses due to increased erosion and decomposition rates and significant increases in content of SOC in no tillage systems as compared to conventional tillage have been reported (Beare 1994; Carvalho et al. 2009; Lal 2004b; Sá et al. 2001). Studies of the effect of tillage on tropical upland soils are, 
however, uncommon. Six et al. (2002) analyzed data from studies of SOC sequestration in no tillage systems compared to conventional tillage and found carbon sequestration rates in tropical soils under no tillage to be $325 \pm$ $113 \mathrm{~kg} \mathrm{C} \mathrm{ha}^{-1}$ year $^{-1}$.

Effects of crop residue management on SOC dynamics were examined by Juo and Lal (1977) who documented SOC losses after maize cultivation to be four times higher when residues were removed from the soil than if they were returned. The importance of residue incorporation in maintaining SOC levels was also demonstrated by Juo et al. (1995) who found SOC content after residue removal to be only $2 / 3$ of the content as compared to when residues were returned to the soil.

\section{Nutrients in Continuous Annual Cropping Systems}

The use of inorganic fertilizers is widespread in the continuous annual cropping systems of Southeast Asia and this may have severe effects on the plot level as well as on the surrounding environment. Excessive use of fertilizer and pesticides are believed to cause eutrophication of surface waters and contamination of ground water in upland agriculture areas where swidden cultivation was once prevalent. This contamination may be a major health hazard to rural populations (Lal 2000; Ziegler et al. 2009).

Nutrient export through harvesting can be substantial in the productive continuous annual cropping systems. To sustain production this export must be compensated for by inputs of inorganic or organic fertilizers. In many cases the inputs made to the soil are, however, drastically lower than the products harvested which will lead to negative nutrient budgets (Lal 2000). Yield declines associated with negative nutrient balances in continuous annual cropping systems in Southeast Asia have been documented by several studies (Fujisaka et al. 1994; Yadav et al. 2000). Micronutrient deficiency and reduced fertilizer use efficiency are other causes of yield declines caused by the sole use of inorganic fertilizers (Altieri and Nicholls 2003; Ladha et al. 2003; Yadav et al. 2000).

The use of inorganic fertilizers without organic amendments for continuous cropping on low fertility soils has in many cases been shown to promote soil acidification accompanied by severe declines in soil quality in terms of reduced cation exchange capacity and high levels of exchangeable Al. In a study from Northern Thailand, Noble et al. (2000) showed that this decline in soil quality will almost be irreversible on light textured soils with limited buffering capacity. The combined use of inorganic fertilizers and manure has, however, been demonstrated to have a positive response on soil quality and yields (Yadav et al. 2000). It is generally not recommended to use inorganic acid forming fertilizers without organic inputs, but it is often beyond the scope of the small scale farmer to apply the large amounts of organic materials needed to amend the negative effects of the inorganic fertilizers, if these are not produced in situ.

\section{Plantations}

\section{Carbon Storage and Soil Quality in Tree Plantations}

Establishment of tree plantations are promoted as an effective method for sequestering $\mathrm{CO}_{2}$ in above- and belowground carbon pools. There is a strong variation in the carbon storage potential among different plantation species and the potential is also affected by management practices and by environmental conditions that can cause significant variations even within a relatively small geographical area (Montagnini and Nair 2004; Schroth et al. 2002).

The influence of soil quality on aboveground carbon storage in plantations was demonstrated by Schroeder (1992) who reported the time-averaged aboveground carbon stock of plantations with Casuarina spp. on sites with moderate soil quality to be $55 \mathrm{Mg} \mathrm{ha}^{-1}$ and only $21 \mathrm{Mg} \mathrm{ha}^{-1}$ on sites with poor soil quality. Carbon accumulation rates of different species used in tropical tree plantations vary considerably and values from less than $1 \mathrm{Mg} \mathrm{ha}^{-1}$ year $^{-1}$ for slow growing species to $7 \mathrm{Mg} \mathrm{ha}^{-1}$ year $^{-1}$ for fast growing species have been reported (Halenda 1993; Montagnini and Porras 1998). The carbon accumulation rate may also vary according to species composition and several studies have reported higher accumulation rates in mixed cultures than in monocultures (Montagnini and Porras 1998; Petit and Montagnini 2006). It has also been suggested that nutrient depletion in soils under mixed cultures is slower than under monospecific stands of fast-growing species (Montagnini 2000).

Rubber is an important tree crop in the upland areas of Southeast Asia, where it is grown in farmer managed rubber gardens as well as in large scale rubber plantations. Time-averaged aboveground carbon stock in permanent rubber agroforests in Indonesia was reported to be about $90 \mathrm{Mg} \mathrm{ha}^{-1}$ while the storage in more intensively managed rotational rubber plantations was in the order of $50 \mathrm{Mg} \mathrm{ha}^{-1}$ (Palm et al. 2005).

In Malaysian Borneo, Tanaka et al. (2009) found soil quality under farmer managed unfertilized rubber gardens to be similar to the quality of soils under secondary forests used for swiddening and concluded that the rubber gardens represented a sustainable land use type at the current low level of tapping intensity. In contrast, a study of more intensified rubber plantations in Peninsular Malaysia reported deteriorated soil physical properties due to topsoil removal and compaction due to mechanical terracing and 
plantation work (Noguchi et al. 2003). Similar results are reported from an intensified rubber plantation in China where rubber cultivation was accompanied by decreased soil $\mathrm{pH}$ levels and high levels of exchangeable Al. The study from China also presents evidence of large exports of basic cations from the soil due to the intensive tapping of rubber latex (Zhang et al. 2007).

Little is known about rates of carbon turnover and carbon storage in soils under tropical tree plantations (Richards et al. 2007) and no studies of the SOC dynamics following transitions from swiddening to plantations have been identified. Contrasting effects of plantation age on the stock of SOC have been reported and studies from research stations in China have shown the content of SOC to decrease with age of rubber plantations (Zhang and Zhang 2005), while other studies have shown SOC to be unaffected by rubber cultivation (Zhang and Zhang 2003). However, when plantations are established on soils that have been used for continuous annual cropping there is generally an initial decrease in SOC followed by an increase (Paul et al. 2002).

Estimates on carbon storage in belowground biomass of tropical plantation species as well as of natural vegetation are based on limited empirical data (Brown 1997; Mokany et al. 2006; Montagnini and Porras 1998; Wauters et al. 2008). The allocation of biomass between roots and aboveground biomass, commonly expressed as the root: shoot ratio is, however, important as the amount of carbon that is allocated to belowground plant parts may be substantial and as roots decay at lower rates than leaf tissue and thus comprise a longer term carbon storage mechanism. The root:shoot ratio is determined by a variety of factors including latitude, tree type, age, climate, water availability, soil quality and soil texture (Cairns et al. 1997; Mokany et al. 2006; Wauters et al. 2008). The root:shoot ratio of moist tropical forests are reported to be about 0.24 , but with large variations due to the heterogeneity of tropical forests and soils (Cairns et al. 1997; Mokany et al. 2006). Plantation species have been shown to generally have a lower root: shoot ratio than natural vegetation (Vogt et al. 1997), but also for plantation species ratios vary considerably. For example, the root:shoot ratios of 5 agroforestry tree species grown under the same conditions on a research station in India, ranged from 0.22 (Bauhinia variegata) to 0.61 (Wendlandia exserta) (Das and Chaturvedi 2008). Very limited carbon allocation to deeper soil layers under a plantation was reported by Richards et al. (2007) who investigated the SOC dynamics under a hoop pine plantation established on a former rainforest site. The SOC content of the subsoil under the hoop pine plantation was reduced by $30 \%$ and $\mathrm{C}$ inputs from the hoop pine were insignificant in the soil layers below $30 \mathrm{~cm}$ where all $\mathrm{SOC}$ was derived from the rainforest.

\section{Carbon Storage and Soil Quality in Oil Palm Plantations}

Oil palm is one of the world's most rapidly expanding tropical crops. The two largest oil palm producing countries are Indonesia ( $>7$ million ha) and Malaysia (3.6 million ha) (Kho and Wilcove 2008; McCarthy and Cramb 2009).

Estimates of the time-averaged aboveground carbon stocks in oil palm plantations are variable. Palm et al. (2005) estimated the time-averaged aboveground carbon stock of Indonesian oil palm plantations with rotation times of 25 years to about $48 \mathrm{Mg} \mathrm{C} \mathrm{ha}^{-1}$ whereas Murdiyarso (2002) estimated the stock to be $91 \mathrm{Mg} \mathrm{C}^{-1}$ in plantations with a 20 year rotation time. Values of $36 \mathrm{Mg}$ $\mathrm{C} \mathrm{ha} \mathrm{h}^{-1}$ have been reported from oil palm plantations in Malaysia (Henson 2003).

Bulldozer clearing and terracing are in many areas the conventional ways of site preparation for oil palm plantations. Bulldozing can remove large amounts of topsoil, causing dramatic decreases in SOC and exposure of the infertile subsoil (Uhl et al. 1982). Moreover, soil compaction associated with mechanical clearing may also be severe and impede root development ( $\mathrm{Lal}$ and Cummings 1979). In a Malaysian oil palm plantation, Hamdan et al. (2000) found that exposure of the subsoil through terracing caused severe degradation of soil quality as it led to high $\mathrm{Al}$ saturation, absence of aggregation, poor water availability and low nutrient contents. The effects reported by Hamdan et al. (2000) are virtually irreversible and will strongly limit choices for other land use options. Tanaka et al (2009) also found loss of topsoil SOC and deterioration of soil physical properties brought about by terrace bench construction in Malaysian oil palm plantations, but concluded that the soils seemed to recover over time due to application of organic materials from the oil palms.

Substantial reductions of the SOC stock of a Nigerian oil palm plantation was documented by Aweto (1995) who found the SOC content to be depleted by more than $50 \%$. This dramatic decrease was ascribed to the lack of canopy closure and the low litter production in the oil palm plantation as compared to natural vegetation. Similar findings have been reported by Sommer et al. (2000) who reported substantial reductions of the SOC stock of an oil palm plantation on an Ultisol in Brazil. SOC stock in the upper $6 \mathrm{~m}$ of the soil of the oil palm plantation was diminished by $50 \mathrm{Mg} \mathrm{ha}^{-1}$ with SOC concentrations under oil palm being lower than under fields used for swiddening throughout the profile. SOC losses under oil palm were most pronounced in the upper $40 \mathrm{~cm}$ where the SOC stock was more than $40 \%$ lower than under swiddening. This considerably lower SOC content of the top soil of the oil palm plantation was ascribed to repeated removal of ground cover causing erosion. 
Sommer et al. (2000) also reported significant reductions in root biomass in soils used for oil palm as compared with secondary vegetation used for swiddening as root $\mathrm{C}$ contents were about ten times higher under secondary vegetation (5-12 years) than under oil palm.

\section{Discussion and Conclusions}

Data on the effects of swiddening on carbon stocks in soil and vegetation is characterized by its scarcity and inconclusiveness as is evidence from the alternative tree based systems. The pool of aboveground biomass is fairly easy to measure but since most allometric equations have been developed for primary forests and not for fallow regrowth, the estimates of aboveground carbon stocks in swidden cultivation are uncertain (Ketterings et al. 2001). Moreover, it is difficult to compare the aboveground carbon storage of different systems as very few studies report the aboveground carbon storage as time-averaged carbon storage. The calculated changes in time-averaged aboveground carbon stocks and in SOC stocks following swidden transformations presented in Table 1 are, therefore, based on a limited number of studies and should only be perceived as rough estimates.

Not surprisingly, transitions to continuous annual cropping systems were found to bring about large reductions in the time-averaged aboveground carbon stocks as were transitions to swidden systems with reduced fallow periods. Most of the reviewed studies found the alternative land use systems to bring about decreased stocks of SOC as compared to swiddening. The uncertainty about the magnitude of these losses is, however, considerable.
Even for substantial topsoil losses of SOC, the impact on the total soil carbon pool may be limited. According to (Batjes 1996) only one third of the SOC in tropical regions is found in the top $30 \mathrm{~cm}$ that is most commonly sampled and most directly affected by land use. Hence, even a $30 \%$ reduction in this pool, will have limited impact on the total carbon stock. However, the associated effects on soil physical and chemical properties associated with such a loss may have much more severe impacts on the soil quality and productivity of the system and may limit farmers' range of land use options.

Due to the difficulty of sampling, carbon inventories that include the deeper soil layers are scarce even though deeper soil layers may contribute considerably to the total soil stock (Aumtong et al. 2009; de Neergaard et al. 2008). It has been documented that the SOC pool of the deeper soil layers may be affected if swidden systems are replaced with plantations with shallower and less roots than secondary vegetation. Assessment of the carbon storage in roots of tree or palm based systems represents a methodological problem as the standard method for measuring root biomass is extremely labour extensive and few allometric equations to estimate tree root biomass in tropical ecosystems exist (Cairns et al. 1997; Mokany et al. 2006; Wauters et al. 2008). Consequently, very few studies have addressed the pool of belowground biomass although it may be of a substantial size and failure to include the pool in carbon inventories may underestimate the total biomass of tree based systems by $50-60 \%$ of aboveground biomass (Brown 1997; Das and Chaturvedi 2008). A recent review of studies on root:shoot ratios in terrestrial ecosystems deemed $62 \%$ of the published root:shoot ratio data points to be methodically inadequate or unverifiable and found reliable

Table 1 Losses of time-averaged aboveground carbon and soil organic carbon following swidden transformations

\begin{tabular}{|c|c|c|c|}
\hline Land use transformation & $\begin{array}{l}\text { Loss of time-averaged } \\
\text { aboveground } \mathrm{C}\end{array}$ & $\begin{array}{l}\text { Loss of } \\
\text { topsoil SOC }\end{array}$ & Sources \\
\hline Traditional swiddening $\rightarrow$ reduced fallow periods & $88-90 \%$ & $0-27 \%$ & $\begin{array}{l}\text { Bruun et al. 2006; Detwiler 1986; } \\
\text { Hashimotio et al. 2000; Jepsen 2006; } \\
\text { Palm et al. } 2005\end{array}$ \\
\hline Traditional swiddening $\rightarrow$ continuous annual cropping & $95-99 \%$ & $13-40 \%$ & $\begin{array}{l}\text { Davidson and Ackerman 1993; } \\
\text { Detwiler 1986; Palm et al. } 2005\end{array}$ \\
\hline Traditional swiddening $\rightarrow$ rubber plantations & $-10-40 \%$ & $0-30 \%$ & $\begin{array}{l}\text { Palm et al. 2005; Sommer et al. 2000; } \\
\quad \text { Tanaka et al. } 2009\end{array}$ \\
\hline Traditional swiddening $\rightarrow$ oil palm plantations & $60 \%$ & $0-40 \%$ & $\begin{array}{l}\text { Palm et al. 2005; Sommer et al. 2000; } \\
\text { Tanaka et al. } 2009\end{array}$ \\
\hline
\end{tabular}

The time-averaged aboveground carbon stock of a swidden system with a rotation time of 25 years as reported by Palm et al. (2005) is used as the baseline value for traditional swiddening. Calculations of time-averaged aboveground carbon stocks in swidden systems with reduced fallow periods (4 years) are based on carbon accumulation rates in fallows presented in the sources and calculated as described in the text, assuming a cropping period of 2 years. The aboveground carbon stock during the cropping period of the swidden cycle is assumed to be $1-2 \mathrm{Mg}$ ha ${ }^{-1}$ and the time-averaged aboveground carbon stock under continuous annual cropping is assumed to be $1-4 \mathrm{Mg}^{-1}$ according to the assumptions described in the text 
data on tropical trees to be especially scarce (Mokany et al. 2006). More empirical studies are needed to elucidate the relationship between root biomass, soil type and management and to improve understanding of the role of roots in the SOC cycle. Moreover, there is a need to develop reliable and feasible methods to determine the root biomass of tropical forest and plantation trees (Mokany et al. 2006).

The ecological aspects of swiddening and of the tree based alternative systems are much more complex than is often presented in the literature and the environmental outcome is to a large extent dependent on the interaction between management issues, criteria used in land use decisions, spatial heterogeneity and external physical parameters. Accordingly, extensively managed rubber plantations as found in Sarawak may not affect soil quality as compared to swiddening, whereas intensified rubber plantations in China and Peninsular Malaysia are associated with severe degradation of soil quality. The practice of mechanical terracing during the establishment of plantations brings about large SOC losses and severe deterioration of soil quality that may be ameliorated with time if organic materials are returned to the soil. Cases of irreversible degradation of soil quality due to mechanical terracing were also found.

It is well known that application of inorganic fertilizers may lead to a deterioration of soil quality if applied on leached tropical soils and without organic amendments. Nonetheless, this practice is often supported by governmental programmes aiming to promote continuous cropping and the practice remains widespread in the continuous annual cropping systems of Southeast Asia. Even if organic material were available it would in most cases be beyond the means of upland farmers to apply this to permanent fields due to the high costs of transporting the bulky organic materials in areas with poor infrastructure. Moreover, the availability of organic materials is often scarce and competition for the residues is high as these have numerous alternative uses including fodder or fuel. These problems could be met by in situ production of organic materials in terms of natural or improved fallows which could also be considered a gradual evolution of swidden cultivation. The use of small amounts of inorganic fertilizers in swidden systems is widespread in Malaysian Borneo and a synthesis of studies from Sarawak found that limited applications of $\mathrm{N}$ and $\mathrm{P}$ fertilizers improved the productivity of traditional swidden systems (Mertz et al. 2008).

Most studies of the effects of land use changes on soil properties have applied the spatial analogue method that involves the comparison of soil samples collected from the land use type under investigation to adjacent forested areas. It is assumed that the soil properties of the forested areas and the cultivated areas were the same before the latter was cultivated and differences are attributed to the land use history of the cultivated fields. These assumptions are in several ways problematic as it has been shown that farmers purposefully select the soils with the highest quality for the more intensive agriculture and use the poorest soils more extensively with longer fallow periods or as forests (Aumtong et al. 2009; Mertz et al. 2008). This brings about a soil quality effect on land use rather than the opposite and may severely compromise the spatial analogue approach. The approach is further compromised by the fact that in upland areas the spatial heterogeneity in terms of soil texture, clay mineralogy and topography is often very high and may override the effects of land use (Bruun et al. 2006; Powers and Veldkamp 2005). Therefore, great caution should be taken before establishing a causal relationship between land use and soil quality. Nevertheless, the majority of the literature on effects of land use changes on soil quality suffers from the assumption that land use is independent of initial soil quality, and that differences in soil quality are caused by land use alone. Future research must explicitly consider the two way interaction between land use and inherent soil quality. Land use independent fertility indicators could be used to account for the effects of inherent fertility and attention should be paid to the ecological considerations behind farmers' land use decisions. Repeated samplings from the same plots under a variety of land uses may-in spite of the obvious disadvantages in terms of duration-still be needed in order to firmly quantify time and management effects on soil quality and carbon stocks. The influence of spatial heterogeneity on the investigated parameters must be carefully considered and effects of e.g. topography and soil type on the storage and dynamics of SOC and soil nutrients must be understood to make valid cross-site comparisons of the environmental consequences of land use transitions.

Acknowledgement We would like to thank the Ford Foundation for funding a workshop in Hanoi in March 2008 where the data for this paper was discussed.

\section{References}

Achard, F., Eva, H. D., Stibig, H.-J., Mayaux, P., Gallego, J., Richards, T., and Malingreau, J. P. (2002). Determination of Deforestation Rates of the World's Humid Tropical Forests. Science 297: 999-1002. doi:10.1126/science.1070656.

Altieri, M. A., and Nicholls, C. I. (2003). Soil Fertility Management and Insect Pests: Harmonizing Soil and Plant Health in Agroecosystems. Soil and Tillage Research 72: 203-211. doi:10.1016/ S0167-1987(03)00089-8.

Andriesse, J. P. (1989). Nutrient management through shifting cultivation. A comparative study on cycling of nutrients in traditional farming systems of Malaysia and Sri Lanka. In van der Heide, J. (ed.), Nutrient Management for Food Crop Production in Tropical Farming Systems. Institute for Soil Fertility and Universitas Brawijaya, Haren, pp. 29-61. 
Andriesse, J. P., and Koopmans, T. T. (1984). A Monitoring Study on Nutrient Cycles in Soils Used for Shifting Cultivation under Various Climatic Conditions in Tropical Asia. I. The Influence of Simulated Burning on Form and Availability of Plant Nutrients. Agriculture, Ecosystems \& Environment 12: 1-16. doi:10.1016/ 0167-8809(84)90057-4.

Andriesse, J. P., and Schelhaas, R. M. (1987a). A Monitoring Study of Nutrient Cycles in Soils Used for Shifting Cultivation under Various Climatic Conditions in Tropical Asia. II. Nutrient Stores in Biomass and Soil—Results of Baseline Studies. Agriculture, Ecosystems \& Environment 19: 285-310. doi:10.1016/0167-8809 (87)90058-2.

Andriesse, J. P., and Schelhaas, R. M. (1987b). A Monitoring Study on Nutrient Cycles in Soils Used for Shifting Cultivation under Various Climatic Conditions in Tropical Asia. III. The Effects of Land Clearing Through Burning on Fertility Level. Agriculture, Ecosystems \& Environment 19: 311-332. doi:10.1016/01678809(87)90059-4.

Arunachalam, A. (2002). Dynamics of Soil Nutrients and Microbial Biomass During First Year Cropping in an 8-year Jhum Cycle. Nutrient Cycling in Agroecosystems 64: 283-291. doi:10.1023/ A:1021488621394.

Aumtong, S., Magid, J., Bruun, S., and de Neergaard, A. (2009). Relating Soil Carbon Fractions to Land Use in Sloping Uplands in Northern Thailand. Agriculture, Ecosystems \& Environment 131: 229-239. doi:10.1016/j.agee.2009.01.013.

Aweto, A. O. (1995). Organic Carbon Diminution and Estimates of Carbon Dioxide Release from Plantation Soil. Environmentalist 15: 10-15. doi:10.1007/BF01888885.

Batjes, N. H. (1996). Total Carbon and Nitrogen in the Soils of the World. European Journal of Soil Science 47: 151-163. doi:1111/ j.1365-2389.1996.tb01386.x.

Beare, M. H. (1994). Aggregate-Protected and Unprotected Organic Matter Pools in Conventional- and No-Tillage Soils. Soil Science Society of America Journal 58: 787-795.

Brady, N. C. (1996). Alternatives to Slash-and-Burn: A Global Imperative. Agriculture, Ecosystems \& Environment 58: 3-11. doi:10.1016/0167-8809(96)00650-0.

Brown, S. (1997). Estimating Biomass and Biomass Change of Tropical Forests, A Primer. FAO Forestry Paper 134. FAO, Rome.

Bruce, J. P., Frome, M., Haites, E., Janzen, H., and Paustian, K. (1999). Carbon Sequestration in Soils. Journal of Soil and Water Conservation 54: 382-389.

Bruun, T. B., Mertz, O., and Elberling, B. (2006). Linking Yields of Upland Rice in Shifting Cultivation to Fallow Length and Soil Properties. Agriculture, Ecosystems \& Environment 113: 139149. doi:10.1016/j.agee.2005.09.012.

Cairns, M. A., Brown, S., Helmer, E. H., and Baumgardner, G. A. (1997). Root Biomass Allocation in the World's Upland Forests. Oecologia 11: 1-11. doi:10.1007/s004420050201.

Carter, M. R., Gregorich, E. G., Anderson, D. W., Doran, J. W., Janzen, H. H., and Pierce, F. J. (1997). Concepts of soil quality and their significance. In Gregorich, E. G., and Carter, M. R. (eds.), Soil Quality for Crop Production and Ecosystem Health. Elsevier, Amsterdam, pp. 1-19.

Carvalho, J. L. N., Cerri, C. E. P., Feigl, B. J., Piccolo, M. C., Godinho, V. P., and Cerri, C. C. (2009). Carbon Sequestration in Agricultural Soils in the Cerrado Region of the Brazilian Amazon. Soil and Tillage Research 103: 342-349. doi:10.1016/ j.still.2008.10.022.

Das, D. K., and Chaturvedi, O. P. (2008). Root Biomass and Distribution of Five Agroforestry Tree Species. Agroforestry Systems 74: 223-230. doi:10.1007/s10457-008-9159-9.

Davidson, E. A., and Ackerman, I. L. (1993). Changes in Soil Carbon Inventories Following Cultivation of Previously Untilled Soils. Biogeochemistry 20: 161-193. doi:10.1007/BF00000786. de Neergaard, A., Magid, J., and Mertz, O. (2008). Soil Erosion from Shifting Cultivation and other Smallholder Land Use in Sarawak, Malaysia. Agriculture, Ecosystems \& Environment 125: 182190. doi:10.1016/j.agee.2007.12.013.

DeBano, L. F., Neary, D. G., and Ffolliott, P. F. (1998). Fire's Effects on Ecosystems. Wiley, New York.

Detwiler, R. (1986). Land Use Change and the Global Carbon Cycle: The Role of Tropical Soils. Biogeochemistry 2: 67-93. doi:10.1007/BF02186966.

Devendra, C., and Thomas, D. (2002). Smallholder Farming Systems in Asia. Agricultural Systems 71: 17-25. doi:10.1016/S0308521X(01)00033-6.

Doran, J. W., and Parkin, T. B. (1994). Defining and assessing soil quality. In Doran, J. W., Coleman, D. C., Bezdicek, D. F., and Steward, B. A. (eds.), Defining Soil Quality for Sustainable Environment. Soil Science of America, Madison, pp. 3-21Special publication No 35 .

Eaton, J. M., and Lawrence, D. (2009). Loss of Carbon Sequestration Potential After Several Decades of Shifting Cultivation in the Southern Yucatan. Forest Ecology and Management (in press).

Ewel, J., Berish, C., Brown, B., Price, N., and Raich, J. (1981). Slash and Burn Impacts on a Costa Rican Wet Forest Site. Ecology 62: 816-829. doi:10.2307/1937748.

Feller, C., and Beare, M. H. (1997). Physical Control of Soil Organic Matter Dynamics in the Tropics. Geoderma 79: 69-116. doi:10.1016/S0016-7061(97)00039-6.

Foody, G. M., Cuttler, M. E., McMorrow, J., Pelz, D., Tangki, H., Boyd, D. S., and Douglas, I. (2001). Mapping the Biomass of Bornean Tropical Rain Forest from Remotely Sensed Data. Global Ecology and Biogeography 10: 379-387. doi:10.1046/ j.1466-822X.2001.00248.x.

Fox, J. (2000). How Blaming 'Slash and Burn' Farmers is Deforesting Mainland Southeast Asia. Asia Pacific Issues 47: 1-8.

Fujisaka, S., Harrington, L., and Hobbs, P. (1994). Rice-Wheat in South Asia: Systems and Long-Term Priorities Established through Diagnostic Research. Agricultural Systems 46: 169187. doi:10.1016/0308-521X(94)90096-X.

Funakawa, S., Tanaka, S., Shinjyo, H., Kaewkhongkha, T., Hattori, T., and Yonebayashi, K. (1997). Ecological Study on the Dynamics of Soil Organic Matter and its Related Properties in Shifting Cultivation Systems of Northern Thailand. Soil Science and Plant Nutrition 43: 681-693.

Garrity, D. P. (1993). Sustainable land-use systems for sloping uplands in South East Asia. In Ragland, J., Lal, R. (eds.), ASA Special Publication No. 56, 41-66.

Giardina, C. P., Sanford, R. L. Jr., Døckersmith, I. C., and Jaramillo, V. J. (2000). The Effects of Slash Burning on Ecosystem Nutrients During the Land Preparation Phase of Shifting Cultivation. Plant and Soil 220: 247-260. doi:10.1023/ A: 1004741125636.

Grace, J. (2004). Understanding and Managing the Global Carbon Cycle. Journal of Ecology 92: 189-202. doi:10.1111/j.00220477.2004.00874.x.

Greenland, D. J. (1975). Bringing the Green Revolution to the Shifting Cultivator. Science 190: 841-844.

Halenda, C. J. (1989). The Ecology of Fallow Forest After Shifting Cultivation in Niah Forest Reserve. Forest Research Report. Forest Department, Kuching.

Halenda, C. J. (1993). Aboveground Biomass Production and Nutrient Accumulation of a Gmelina arborera Plantation in Sarawak, Malaysia. Journal of Tropical Forest Science 5: 429-439.

Hamdan, J., Burnham, C. P., and Ruhana, B. (2000). Degradation Effect of Slope Terracing on Soil Quality for Elaeis guineensis Jacq. (Oil Palm) Cultivation. Land Degradation \& Development 11: 181-193. doi:10.1002/(SICI) 1099-145X(200003/04) 11:2<181::AID-LDR377>3.0.CO;2-U. 
Harwood, R. R. (1996). Development Pathways Toward Sustainable Systems Following Slash-and-Burn. Agriculture, Ecosystems and Environment 58: 75-86. doi:10.1016/0167-8809(95)00655-9.

Hashimotio, T., Kojima, K., Tange, T., and Sasaki, S. (2000). Changes in Carbon Storage in Fallow Forests in the Tropical Lowlands of Borneo. Forest Ecology and Management 126: 331-337. doi:10.1016/S0378-1127(99)00104-8.

Henson, I. E. (2003). The Malaysian National Average Oil Palm: Concept and Evaluation. Oil Palm Bulletin 14: 15-27.

Hölscher, D., Ludwig, B., Moller, R. F., and Folster, H. (1997). Dynamic of Soil Chemical Parameters in Shifting Agriculture in the Eastern Amazon. Agriculture, Ecosystems and Environment 66: 153-163. doi:10.1016/S0167-8809(97)00077-7.

Houghton, R. A., Skole, D. L., and Lefkowitz, D. S. (1991). Changes in the Landscape of Latin America between 1850 and 1985 Forest II. Net Release of $\mathrm{CO}_{2}$ to the Atmosphere. Ecology and Management 38: 173-199. doi:10.1016/0378-1127(91)90141-H.

Hughes, R. F., Kauffman, J. B., and Cummings, D. L. (2000). Fire in the Brazilian Amazon. Oecologia 124: 574-588. doi:10.1007/ s004420000416.

Ingram, J. S. I., and Fernandes, E. C. M. (2001). Managing Carbon Sequestration in Soils: Concepts and Terminology. Agriculture, Ecosystems \& Environment 87: 111-117. doi:10.1016/S01678809(01)00145-1.

IPCC. (2007). Synthesis report. An Assessment of the Intergovernmental Panel on Climate Change. Valencia.

Jepsen, M. R. (2006). Above-Ground Carbon Stocks in Tropical Fallows, Sarawak, Malaysia. Forest Ecology and Management 225: 287-295. doi:10.1016/j.foreco.2006.01.005.

Jobbaggy, E. G., and Jackson, R. B. (2000). The Vertical Distribution of Soil Organic Carbon and its Relation to Climate and Vegetation. Ecological Applications 10: 423-436. doi:10.1890/ 1051-0761(2000)010[0423:TVDOSO]2.0.CO;2.

Johnson, C. M., Vieira, I. C. G., Zarin, D. J., and Frizano, J. (2001). Carbon and Nutrient Storage in Primary and Secondary Forest in Eastern Amazônia. Forest Ecology and Management 147: 245252. doi:10.1016/S0378-1127(00)00466-7.

Jordan, C. F. (1985). Nutrient Cycling in Tropical Forest Ecosystems. Principles and their Practical Application in Management of Conservation. Wiley, New York.

Jordan, C. F. (1989). An Amazonian Rain Forest. The Structure and Function of a Nutrient Stressed Ecosystem and the Impact of Slash-and-burn Agriculture. Parthenon, Lancs.

Juo, A. S. R., and Lal, R. (1977). The Effect of Fallow and Continuous Cultivation on the Chemical and Physical Properties of an Alfisol in Western Nigeria. Plant and Soil 47: 567-584. doi:10.1007/BF00011027.

Juo, A. S. R., and Manu, A. (1996). Chemical Dynamics in Slash-andBurn Agriculture. Agriculture, Ecosystems and Environment 58: 49-60. doi:10.1016/0167-8809(95)00656-7.

Juo, A. S. R., Franzluebbers, K., Dabiri, A., and Ikhile, B. (1995). Changes in Soil Properties during Long-Term Fallow and Continuous Cultivation after Forest Clearing in Nigeria. Agriculture, Ecosystems \& Environment 56: 9-18. doi:10.1016/01678809(95)00635-4.

Kauffman, J. B., Sanford, R. L., Cummings, D. L., Salcedo, I. H., and Sampaio, E. V. S. B. (1993). Biomass and Nutrient Dynamics Associated with Slash Fires in Neotropical Dry Forests. Ecology 74: 140-151. doi:10.2307/1939509.

Kennard, D. K., and Gholz, H. L. (2001). Effects of High- and Lowintensity Fires on Soil Properties and Plant Growth in a Bolivian Dry Forest. Plant and Soil 234: 119-129. doi:10.1023/ A:1010507414994.

Ketterings, Q. M., Ceo, R., van Noordwijk, M., Ambagau, Y., and Palm, C. (2001). Reducing Uncertainty in the Use of Allometric Biomass Equations for Predicting Above-Ground Tree Biomass in Mixed Secondary Forests. Forest Ecology and Management 146: 199-209. doi:10.1016/S0378-1127(00)00460-6.

Kho, L. P., and Wilcove, D. S. (2008). Is Oil Palm Agriculture Really Destroying Tropical Biodiversity. Conservation Letters 1: 60-64. doi:10.1111/j.1755-263X.2008.00011.x.

Kleinman, P. J. A., Pimentel, D., and Bryant, R. B. (1995). The Ecological Sustainability of Slash-and-Burn Agriculture. Agriculture, Ecosystems \& Environment 52: 235-249. doi:10.1016/ 0167-8809(94)00531-I.

Kleinman, P. J. A., Bryant, R. B., and Pimentel, D. (1996). Assessing Ecological Sustainability of Slash-and-Burn Agriculture through Soil Fertility Indicators. Agronomy Journal 88: 122-127.

Ladha, J. K., Dawe, D., Pathak, H., Padre, A. T., Yadav, R. L., Singh, B., Singh, Y., Singh, Y., Singh, P., Kundu, A. L., Sakal, R., Ram, N., Regmi, A. P., Gami, S. K., Bhandari, A. L., Amin, R., Yadav, C. R., Bhattarai, E. M., Das, S., Aggarwal, H. P., Gupta, R. K., Hobbs, P. R. (20-2-2003). How Extensive are Yield Declines in Long-Term Rice-Wheat Experiments in Asia? Field Crops Research 81: 159-180. doi:10.1016/S0378-4290(02)00219-8.

Lal, R. (1997). Degradation and Resilience of Soils. Philosophical Transactions of the Royal Society of London Series BBiological Sciences 352: 869-889. doi:10.1098/rstb.1997.0078.

Lal, R. (2000). Soil Management in Developing Countries. Soil Science 165: 57-72. doi:10.1097/00010694-200001000-00008.

Lal, R. (2004a). Soil Carbon Sequestration Impacts on Global Climate Change and Food Security. Science 304: 1623-1627. doi:10.1126/science.1097396.

Lal, R. (2004b). Soil Carbon Sequestration to Mitigate Climate Change. Geoderma 123: 1-22. doi:10.1016/j.geoderma.2004. 01.032 .

Lal, R., and Bruce, J. P. (1999). The Potential of World Cropland Soils to Sequester C and Mitigate the Greenhouse Effect. Environmental Science \& Policy 2: 177-185. doi:10.1016/S1462-9011 (99)00012-X.

Lal, R., and Cummings, D. J. (1979). Clearing a Tropical Forest I. Effects on Soil and Micro-climate. Field Crops Research 2: 91107. doi:10.1016/0378-4290(79)90012-1.

Lawrence, D., and Schlesinger, W. H. (2001). Changes in Soil Phosphorus during 200 Years of Shifting Cultivation in Indonesia. Ecology 82: 2769-2780.

Lawrence, D., Suma, V., and Mogea, J. P. (2005). Change in Species Composition with Repeated Shifting Cultivation: Limited Role of Soil Nutrients. Ecological Applications 15: 1952-1967. doi:10.1890/04-0841.

Lawrence, D., D’Odorico, P., DeLonge, M., Diekmann, L., Das, R., and Eaton, J. M. (2007). Ecological Feedbacks Following Deforestation Create the Potential for a Catastrophic Ecosystem Shift in Tropical Dry Forest. Proceedings of the National Academy of Sciences 104: 20696-20701. doi:10.1073/pnas. 0705005104.

McCarthy, J. F., and Cramb, R. A. (2009). Policy Narratives, Landholder Engagement, and Oil Palm Expansion on the Malaysian and Indonesian Frontiers. The Geographical Journal 175: $112-123$.

Mertz, O. (2002). The Relationship Between Fallow Length and Crop Yields in Shifting Cultivation: A Rethinking. Agroforestry Systems 55: 149-159. doi:10.1023/A:1020507631848.

Mertz, O., Wadley, R. L., Nielsen, U., Bruun, T. B., Colfer, C. J. P., de Neergaard, A., Jepsen, M. R., Martinussen, T., Zhao, Q., Noweg, G. T., and Magid, J. (2008). A Fresh Look at Shifting Cultivation: Fallow Length an Uncertain Indicator of Productivity. Agricultural Systems 96: 75-84. doi:10.1016/j.agsy.2007.06.002.

Mokany, K., Raison, R. J., and Prokushkin, A. S. (2006). Critical Analysis of Root:Shoot Ratios in Terrestrial Biomes. Global Change Biology 12: 84-96. doi:10.1111/j.1365-2486.2005. 001043.x. 
Montagnini, F. (1-9-2000). Accumulation in Above-Ground Biomass and Soil Storage of Mineral Nutrients in Pure and Mixed Plantations in a Humid Tropical Lowland. Forest Ecology and Management 134: 257-270. doi:10.1016/S0378-1127(99)00262-5.

Montagnini, F., and Nair, P. K. R. (2004). Carbon Sequestration: An Underexploited Environmental Benefit of Agroforestry Systems. Agroforestry Systems 61: 281-295. doi:10.1023/B:AGFO. 0000029005.92691.79.

Montagnini, F., and Porras, C. (1998). Evaluating the Role of Plantations as Carbon Sinks: An Example of an Integrative Approach from the Humid Tropics. Environmental Management 22: 459-470. doi:10.1007/s002679900119.

Murdiyarso, D., van Noordwijk, M., Wasrin, U. R., Tomich, T. P., and Gillison, A. N. (2002). Environmental Benefits and Sustainable Land-Use Options in the Jambi Transect, Sumatra. Journal of Vegetation Science 13: 429-438.

Murty, D., Kirschbaum, M. U. F., Mcmurtrie, R. E., and Mcgilvray, H. (2002). Does Conversion of Forest to Agricultural Land Change Soil Carbon and Nitrogen? A Review of the Literature. Global Change Biology 8: 105-123. doi:10.1046/j.1354-1013.2001. 00459.x.

Mutuo, P., Cadisch, G., Albrecht, A., Palm, C., and Verchot, L. (2005). Potential of Agroforestry for Carbon Sequestration and Mitigation of Greenhouse Gas Emissions from Soils in the Tropics. Nutrient Cycling in Agroecosystems 71: 43-54. doi:10.1007/s10705-004-5285-6.

Nielsen, U., Mertz, O., and Noweg, G. T. (2006). The Rationality of Shifting Cultivation Systems: Labor Productivity Revisited. Human Ecology 34: 210-218. doi:10.1007/s10745-006-9014-4.

Noble, A. D., Gillman, G. P., and Ruaysoongnern, S. (2000). A Cation Exchange Index for Assessing Degradation of Acid Soil by Further Acidification under Permanent Agriculture in the Tropics. European Journal of Soil Science 51: 233-243. doi:10.1046/j.1365-2389.2000.00313.x.

Noguchi, S., Kasran, S., Yosup, Z., Tsuboyama, Y., and Tani, M. (2003). Depth and Physical Properties of Soil in a Forest and a Rubber Plantation in Peninsular Malaysia. Journal of Tropical Forest Science 15: 513-530.

Nye, P. H., and Greenland, D. J. (1964). Changes in the Soil after Clearing Tropical Forest. Plant and Soil 21: 101-112. doi:10.1007/BF01373877.

Padoch, C., Coffey, K., Mertz, O., Leisz, S., Fox, J., and Wadley, R. L. (2007). The Demise of Swidden in Southeast Asia? Local Realities and Regional Ambiguities. Geografisk TidsskriftDanish Journal of Geography 107: 29-41.

Palm, C. A., Swift, M. J., and Woomer, P. L. (1996). Soil Biological Dynamics in Slash-and-Burn Agriculture. Agriculture, Ecosystems and Environment 58: 61-74. doi:10.1016/0167-8809(95) 00653-2.

Palm, C. A., van Noordwijk, M., Woomer, P., Alegre, J. C., Arévalo, L., Castilla, C. E., Cordeiro, D. G., Hairiah, K., Kotto-Same, J., Moukam, A., Parton, W. J., Ricse, A., Rodrigues, V., and Sitompul, S. M. (2005). Carbon losses and sequestration after land use changes on the humid tropics. In Palm, C. A., Vosti, S. A., Sanchez, P. A., and Ericksen, P. J. (eds.), Slash-and-Burn Agriculture-The Search for Alternatives. Columbia University Press, New York, pp. 41-63.

Paul, K. I., Polglase, P. J., Nyakuengama, J. G., and Khanna, P. K. (19-2002). Change in soil carbon following afforestation. Forest Ecology and Management 168: 241-257. doi:10.1016/S03781127(01)00740-X.

Petit, B., and Montagnini, F. (15-9-2006). Growth in Pure and Mixed Plantations of Tree Species Used in Reforesting Rural Areas of the Humid Region of Costa Rica, Central America. Forest Ecology and Management 233: 338-343. doi:10.1016/j.foreco. 2006.05.030.
Powers, J. S., and Veldkamp, E. (2005). Regional Variation in Soil Carbon and Delta C13 Signature in Forests and Pastures of Northeastern Costa Rica. Biogeochemistry 72: 315-336. doi:10.1007/s10533-004-0368-7.

Ramakrishnan, P. S., and Toky, O. P. (1981). Soil Nutrient Status of Hill Agro-ecosystems and Recovery Pattern after Slash and Burn Agriculture (Jhum) in North-Eastern India. Plant and Soil 60: 4164. doi:10.1007/BF02377111.

Rerkasem, K., Lawrence, D., Padoch, C., Schmidt-Vogt, D., Ziegler, A. D., and Bruun, T. B. (2009). Consequences of swidden transitions for crop and fallow biodiversity in Southeast Asia. Human Ecology, this issue.

Richards, A. E., Dalal, R. C., and Schmidt, S. (2007). Soil Carbon Turnover and Sequestration in Native Subtropical Tree Plantations. Soil Biology and Biochemistry 39: 2078-2090.

Roder, W., Phengchanh, S., and Keoboulapha, B. (1995). Relationships Between Soil, Fallow Period, Weeds and Rice Yield in Slash-and-Burn Systems of Laos. Plant and Soil 176: 27-36. doi:10.1007/BF00017672.

Roder, W., Phengchanh, S., and Maniphone, S. (1997). Dynamics of Soil and Vegetation During Crop and Fallow Period in Slash-andBurn Fields of Northern Laos. Geoderma 76: 131-144. doi:10.1016/S0016-7061(96)00100-0.

Romanyá, J., Casals, P., and Vallejo, V. R. (2001). Short Term Effects of Fire on Soil Nitrogen Availability in Mediterranean Grasslands and Shrublands Growing in Old Fields. Forest Ecology and Management 147: 39-53. doi:10.1016/S0378-1127(00)00433-3.

Ruthenberg, H. (1980). Farming Systems in the Tropics. Clarendon, Oxford.

Sá, J. C., Cerri, C. C., Dick, W. A., Lal, R., Venzke Filho, S. P., Piccolo, M. C., and Feigl, B. J. (2001). Organic Matter Dynamics and Carbon Sequestration for a Tillage Chronosequence in a Brazilian Oxisol. Soil Science Society of America Journal 65: 1486-1499.

Saa, A., Trasar-Cepeda, M. C., Gil-Sotres, F., and Carballas, T. (1993). Changes in Soil Phosphorus and Acid Phosphatase Activity Immediately Following Forest Fires. Soil Biology and Biochemistry 25: 1223-1230. doi:10.1016/0038-0717(93)90218-Z.

Sanchez, P. A. (1976). Properties and Management of Soils in the Tropics. Wiley, New York.

Sanchez, P. A., Bandy, D. E., Villachica, J. H., and Nicholaides, J. J. (1982). Amazon Basin Soils: Management for Continuous Crop Production. Science 216: 821-827. doi:10.1126/science.216. 4548.821.

Sarmiento, L., and Bottner, P. (2002). Carbon and Nitrogen Dynamics in Two Soils with Different Fallow Times in the High Tropical Andes: Indications for Fertility Restoration. Applied Soil Ecology 19: 79-89. doi:10.1016/S0929-1393(01)00178-0.

Schlesinger, W. H., and Andrews, J. A. (2000). Soil Respiration and the Global Carbon Cycle. Biogeochemistry 48: 7-20. doi:10.1023/A:1006247623877.

Schmidt-Vogt, D., Leisz, S., Mertz, O., Heinimann, A., Thiha, Messerli, P., Epprecht, M., Cu, P. V., Chi, K., Hardino, M., and Truong, D. (2009). An Assessment of Trends in the Extent of Swidden in Southeast Asia. Human Ecology, this issue.

Schroeder, P. (1992). Carbon Storage Potential of Short Rotation Tropical Tree Plantations. Forest Ecology and Management 50: 31-41. doi:10.1016/0378-1127(92)90312-W.

Schroth, G., D'Angelo, S. A., Teixeira, W. G., Haag, D., and Lieberei, R. (2002). Conversion of Secondary Forest into Agroforestry and Monoculture Plantations in Amazonia: Consequences for Biomass, Litter and Soil Carbon Stocks after 7 years. Forest Ecology and Management 163: 131-150. doi:10.1016/S0378-1127(01) 00537-0.

Six, J., Feller, C., Denef, K., Ogle, S. M., Moraes, J. C., and Albrecht, A. (2002). Soil Organic Matter, Biota and Aggregation in 
Temperate and Tropical Soils-Effects of No-Tillage. Agronomie 22: 755-775. doi:10.1051/agro:2002043.

Sommer, R., Denich, M., and Vlek, P. L. G. (2000). Carbon Storage and Root Penetration in Deep Soils Under Small-Farmer LandUse Systems in the Eastern Amazon Region, Brazil. Plant and Soil 219: 231-241. doi:10.1023/A:1004772301158.

Swamy, P. S., and Ramakrishnan, P. S. (1988). Nutrient Budget under Slash and Burn Agriculture (Jhum) with Different Weeding Regimes in North-Eastern India. Acta Oecologica 9: 85-102.

Szott, L. T., Palm, C. A., and Buresh, R. J. (1999). Ecosystem Fertility and Fallow Function in the Humid and Subhumid Tropics. Agroforestry Systems 47: 163-196. doi:10.1023/A:1006215430432.

Tanaka, S., Tachibe, S., Wasli, M. E. B., Lat, J., Seman, L., Kendawang, J. J., Iwasaki, K., and Sakurai, K. (2009). Soil Characteristics under Cash Crop Farming in Upland Areas of Sarawak, Malaysia. Agriculture, Ecosystems \& Environment 129: 293-301. doi:10.1016/j.agee.2008.10.001.

Tinker, P. B., Ingram, J. S. I., and Struwe, S. (1996). Effects of Slashand-Burn Agriculture and Deforestation on Climate Change. Agriculture, Ecosystems \& Environment 58: 13-22. doi:10.1016/ 0167-8809(95)00651-6.

Uhl, C. (1987). Factors Controlling Succession Following Slash-andBurn Agriculture in Amazonia. Journal of Ecology 75: 377-407. doi: $10.2307 / 2260425$.

Uhl, C., Jordan, C., Clark, K., Clark, H., and Herrera, R. (1982). Ecosystem Recovery in Amazon Caatinga Forest after Cutting, Cutting and Burning, and Bulldozer Clearing Treatments. Oikos 38: 313-320. doi: $10.2307 / 3544671$.

van Noordwijk, M., Cerri, C., Woomer, P. L., Nugroho, K., and Bernoux, M. (1997). Soil Carbon Dynamics in the Humid Tropical Forest Zone. Geoderma 79: 187-225. doi:10.1016/ S0016-7061(97)00042-6.

Vogt, K., Asbjornsen, H., Ercelawn, A., Montagnini, F., and Valdes, M. (1997). Roots and mycorrhizas in plantation ecosystems. In
Nambiar, E. K. S., and Brown, A. G. (eds.), Management of Soil. Water and Nutrients in Tropical Plantation Forests, ACIAR Monograph, Melbourne, pp. 247-289, No. 43.

Wauters, J. B., Coudert, S., Grallien, E., Jonard, M., and Ponette, Q. (2008). Carbon Stock in Rubber Tree Plantations in Western Ghana and Mato Grosso (Brazil). Forest Ecology and Management 255: 2347-2361. doi:10.1016/j.foreco.2007.12.038.

Whitmore, T. C. (1998). An Introduction to Tropical Rain Forests. Oxford University Press, Oxford.

Yadav, R. L., Dwivedi, B. S., Prasad, K., Tomar, O. K., Shurpali, N. J., and Pandey, P. S. (2000). Yield Trends, and Changes in Soil Organic-C and Available NPK in a Long-Term Rice-Wheat System under Integrated Use of Manures and Fertilisers. Field Crops Research 68: 219-246. doi:10.1016/S0378-4290(00) 00126-X.

Young, A. (1997). Agroforestry for Soil Management. CAB International and ICRAF, Oxon.

Zhang, H., and Zhang, G. L. (2003). Microbial Biomass Carbon and Total Organic Carbon of Soils as Affected by Rubber Cultivation. Pedosphere 13: 353-357.

Zhang, H., and Zhang, G. L. (2005). Landscape-Scale Soil Quality Change Under Different Farming Systems of a Tropical Farm in Hainan, China. Soil Use and Management 21: 58-64. doi:10.1079/SUM2005293.

Zhang, H., Zhang, G. L., Zhao, Y. G., Zhao, W. J., and Qi, Z. P. (2007). Chemical Degradation of a Ferralsol (Oxisol) Under Intensive Rubber (Hevea brasiliensis) Farming in Tropical China. Soil and Tillage Research 93: 109-116. doi:10.1016/j.still.2006. 03.013.

Ziegler, A. D., Agus, F., Bruun, T. B., van Noordwijk, M., Lam, N. T., Lawrence, D., Rerkasem, K., and Padoch, C. (2009). Environmental consequences of the demise in swidden agriculture in Montane Mainland SE Asia: Hydrology and geomorphology. Human Ecology, this issue. 